\title{
Investigation on the Intake of Part-time Job Practice into the University Curriculum Category
}

\author{
Yang Jian-Di \\ Guangxi Normal University for Nationalities, Chongzuo City, Guangxi, China
}

\begin{abstract}
With the development of the economic, there are both advantages and disadvantages for parttime job to the graduates, and what the university administrators should do with such a personal behavior is to make some reform onto the curriculum setting, except to guide it towards good effects. Based on recognizing the rationality of part-time job, this dissertation detects their pros and cons of the part-time work practice through questionnaire and interview research, analyzes the causes and provides some suggestions.
\end{abstract}

KEYWORD: Part-time Work Practice; Investigation; Curriculum Setting; Suggestions

\section{INTRODUCTION}

Part-time practice has already become a very widespread phenomenon in college campus. There are three main purposes pushing them do that: financial rewards, more knowledge about society and more confidence for future employment. However, taking part-time job practice has also raised many problems, such as salary or other personal interests that cannot be given on time, and how to arrange work and study time. What kind of part-time job can be firstly selected is concerned about the benefit you get and how it adjunct to maximize personal growth instead of financial reward. In order to further understand the deep reasons of these problems, the investigation and analysis about the intake of part-time job practice into the university curriculum category is necessary. The study, named "Jian Qiao Staff Leasing Agent", is included in the student's "Innovation and Entrepreneurship Projects" held among Guangxi universities, and it takes Guangxi Normal University for Nationalities and Chongzuo city as the survey site. The author conducted some questionnaires and interviewed some related objects. Then, the author combined the results and analyzed the feasibility of the part-time job practice in the college curriculum.

\section{RESEARCH METHODS}

\subsection{Sample}

A sample of questionnaire, which is concerning about the part-time job practice, has been used, recovering 547 valid questionnaires among the 600 in total. The survey objective included some classes in all 9 departments of GXNUN as well as the members in Employment and Enterprise Promotion Association, and students from all kinds associations accounted for about 30\%. Meanwhile, the author interviewed 16 persons including related personnel in and out of college. All we want to know is different views and opinions about part-time job practice and its security issues. As for the Business English students, this survey also conducted 40 pieces of questionnaires to further explore the scope of part-time job undergraduate and the feasibility of part-time job practice.

The whole survey covers the entire college system in different department and grades, so that to increase the accuracy and extensive of the survey. Then, interviewees include leaders from government to small units, teachers and students with part-time jobs, ranged from 20-40. Thus, the results is more comprehensively representative.

\subsection{Measuring Tools}

The author made three dimensional version questionnaires. The type of questionnaire $\mathrm{A}$ is a common issue one, while questionnaire $\mathrm{B}$ is the combination of Richter scale and common questionnaire. The body of questionnaires is all arranged from common questions slowly into main topic of the study. (Yi-hong Gao: 2003) Finally, three different copies of the questionnaire are distributed to three different specific targeted groups in order to increase the accuracy of survey.

\subsection{Data Analysis}

As for the statistical analysis, the author makes use of the quantitative analysis. 


\subsubsection{Survey Data Analysis}

There are 547 questionnaires valid among the issued 600 questionnaires from students. Through the investigation, students had part-time experiences accounted $70.9 \%$, which is three times than who did not have.

For students majoring Business English, the author has handed out 40 pieces of questionnaires, recovering 39 effective ones, of which $84.6 \%$, ie.33 students who have ever done part-time job in the past or now, and of which $76.9 \%$ did not related to their major. When choosing par-time job, there are some defects due to students cannot choose the most suitable jobs for them. More than half of part-time jobs do not related to students' profession, which reflects that college student lack of proper values of part-time job practice.

The survey shows $76.9 \%$ of students are not satisfied with the curriculum-setting, more than $61.5 \%$ students think part-time job practice should be included in main courses in the undergraduate education. In addition, it shows that college students eager to have access to social. In another hand, they are limited by school curriculum at this stage, whose distribution is not so reasonable now.

Table 1 results of the data analysis of the survey

\begin{tabular}{|l|l|l|l|l|}
\hline $\begin{array}{l}\text { Questionnaire survey } \\
\text { object }\end{array}$ & $\begin{array}{l}\text { role or purpose of } \\
\text { part-time practice }\end{array}$ & $\begin{array}{l}\text { cumulative } \\
\text { percentage }\end{array}$ & contact of part-time practice with employment & $\begin{array}{l}\text { cumu-lative } \\
\text { per-centage }\end{array}$ \\
\hline $\begin{array}{l}\text { All classes of whole 9 } \\
\text { ministry and members } \\
\text { of Employment and } \\
\begin{array}{l}\text { Enterprise Promotion } \\
\text { Association }\end{array}\end{array}$ & $\begin{array}{l}\text { exercising their own } \\
\text { quality, and enhancing } \\
\text { their abilities }\end{array}$ & $76.6 \%$ & $\begin{array}{l}\text { gaining ex-perience and putting knowledge } \\
\text { into practice }\end{array}$ & $60.73 \%$ \\
\cline { 2 - 5 } & Material rewards & $23.4 \%$ & $\begin{array}{l}\text { excercising will, as well as reducing the burden } \\
\text { on the family }\end{array}$ & $5.18 \%$ \\
\cline { 3 - 6 }
\end{tabular}

\subsubsection{Analysis of Interview Survey}

From interviews with senior students in internships, many of them expressed that they have encountered a lot of confusion about how to put class knowledge into practical use, as well as some problems in interpersonal, emotional control, work expectation choices, etc. A senior student majoring in Business English leaves the following understanding after experiencing 3 months of internship. Students learned foreign trade and had studied foreign trade correspondence course in college, in which teachers teach again and again how to write business letters like how to inquiry and make counter-offer. In fact, all these teaching materials are almost written by some scholars and out of date yet. This shows that there are some difficulties on how to transform textbook knowledge into an efficiency of society for a fresh graduated who just learning social contact. And it needs to overcome some hard time to adapt the social work.

Through interviews both in and out of college, the targeted interviewees from Human Resources and Social Security Bureau of Chongzuo City, Career Department GXNUN and some relevant departments, 15 of them appointed that "students having appropriate extra-curricular part-time job practice would be able to accumulate some social experience, and speed up the pace of adapting society." The 10 interviewed teachers and directors said that "part-time job practice is good without doubt, but the allocation of time should be noticed". Numbers of teachers stress that, it didn't matter for anyone to find the professional part-time job practice, because any practice can accumulate social experiences, as well as dealing with the methods in the future employment orientation. Of course, there are also such views, too original part-time job practice (i.e. purely physical labor, etc.), cannot help to learn much, but will affect the learning energy. In the surveys of enterprises in Chongzuo city, leaders said that it is the responsibility of college to teach students, instead of entrepreneur, so they believe that it will be fine calling for a ready working man rather than a learning student.

\section{SURVEY RESULTS AND KEY FINDINGS}

\subsection{Survey Results}

All social, college and students themselves recognized the benefits from part-time job practice, but many students cannot choose correctly between financial reward and social experience growing. This can be reflected in more than half of students choosing financial types instead of professionalrelated practices. So, many students want to have professional curriculum guidance to help them establish correct concept and make part-time experience become rational part of their career planning. Therefore, the part-time job practice courses are welcome. From the investigation, 33.3\% students tent to have part-time job courses at junior year, and $25.6 \%$ students tent to have it at sophomore year, while $20.5 \%$ students chose freshman year, and $20.5 \%$ selected senior year. In that circumstance, college students will be more delighted that the part-time curriculum courses is arranged at sophomore and junior year. There will be 
some difficulties for freshman to adapt the college system and learning methods, while seniors will face with the internships and thesis work. Thus, sophomore and junior year will be the best choice for part-time practice.

In the investigation, $38.5 \%$ students want to have part-time practice class at the weekend, and $38.5 \%$ want to do it in the summer and winter vacations, while only $23.1 \%$ choose the normal teaching time. Thus, part-time job practice classes being set up on weekends or in summer and winter vacations is more suitable for students, due to normal learning tasks has distracted students. Then, students can finish part-time practice tasks on weekends, summer and winter vacations. Without the pressure of learning, students can better experience the job they do.

\subsection{Main Findings}

Through the investigation, it is known that students, fresh graduates and school teachers, all of them attach great importance to part-time job practice, which is the important key to make connection with society and provides good opportunities to acquaint the future work. At the same time, students can also accumulate valuable experience for themselves. Thus, students think part-time job practice can make up for lack of knowledge in the class, understand the up-to-date knowledge, and fully develop their comprehensive abilities in the process, so that the rate of success will be increased when having graduation employment. Benefits can be brought in clearly by part-time job practice for personal, which is accompanied with problems that cannot be ignored. For example, personal safety in the process of looking for part-time job practice, personal rights during practice, and how to minimize losses, etc. All of above are closely related with the interests of students with part-time jobs. In that circumstance, in the process of looking for part-time job practice and selection, people usually concern much more about the problems on how to make the real value parttime job practice different from the pure economic efficiency, and enables it to achieve the maximization value for students' own development. Traditional part-time job practice types such as promotion and distributing handbills are relatively common in Chongzuo City. There are two main reasons for this phenomenon. First, the economic situation in Chongzuo is not developed very much, and many industries are not perfect developed. Second, students' concept of part-time was not correctly guided, and the majority simply chooses the economic compensation for the purpose of practice. The investigation finds that students who work for pure physical part-time are in lower grades. Junior or senior students, in some extent, know the social situation and the types of talent required, so what their desire is get more experience and skills.
Pity is that the economic situation is limited in Chongzuo city, so the regular formal part-time jobs offered are very few. How to find the appropriate training opportunities within the limitation of economic status in Chongzuo city, and how to correctly lead students to select suitable part-time job practice and so on, all these problems are concerned much by college students.

\section{SUGGESTIONS ABOUT INTAKE OF PART- TIME JOB PRACTICE INTO COLLEGE COURSE CATEGORIES}

\subsection{Cooperation between Colleges and Enterprises}

It is known that many colleges have established some departments or organizations specially serving for graduate students' employment, such as Department of Students Work or The Student Career Organization, and Employment and Enterprise Promotion Association. All these organizations or units provide very important help in graduates' employment, which made a great contribution to graduates. However, all that only serves for the graduates' employment, but not including students in college. It is believed that this kind of department or organization should also pay attention to nongraduate students who looking for part-time jobs. Thus, this ease the pressure of employment department, and students can improve their employment confidence. Furthermore, students and enterprises can have much more bilateral-choices between them. Colleges can establish some cooperation with some entrepreneurs on the basis of annual graduate recruitment at campus, and these two parties together can solve the employment problems of graduates easily.(Xin Zhu: 2011) If colleges and enterprises can work together to make a long-term employment programs, and students are encouraged actively to participate in the plan so that they will begin to owe this kind of consciousness about making full preparation for the graduation. It is believed that this plan will be popular among students, and it is beneficial to colleges, students and enterprises.

\subsection{Putting Part-Time Job Practice into College Course Categories}

College students' long-term employment practice training plan is that students participating in parttime job practice curriculum and actively completing curriculum learning task under the guidance of professional teachers and taking part in some parttime job practice themselves. (Ting-ting Wen: 2012) This plan provides as many opportunities as possible for students to practice to get more knowledge and experience. Talent students with certain professional knowledge and real work experience are what social 
really need. This training plan meets the needs of society, makes students become real talents to society and also have more confidence when graduating. Furthermore, the plan requires support of professional part-time job practice course and some guidance from professional college teachers.

College part-time job practice course is a course learning knowledge combined with inside and outside college, and what different from the usual course is that this course calls for very high degree of adaptability of students with part-time job practice. (Qi-bao Tang: 2008) In the other hand, students are encouraged to actively participate in social practice to find their own practice platform.

\subsubsection{Course Content}

Course content can be classified into two categories, professional learning in class and curriculum with practice outside class. The class curriculum means special employment guidance from professional teachers carrying out special part-time job practice knowledge course, leading students to learn some related part-time job practice course requirements, as well as guiding students to complete a part-time career planning, and making it become a part of the student occupation career planning. As for the practice outside class, it is following the occupation planning instruction in the class, obeying the introduction of college or relevant departments, going to enterprises to participate in corresponding part-time job practice.

\subsubsection{Course Form}

Course form can be divided into professional practice and extended practice. Professional practice means a student having its part-time job practice with basic professional knowledge, so that it can make students combine professional knowledge with the actual work in advance. On the other hand, for the problems they have met when working, they can discuss with teachers to look for causes and solutions together. The more important thing is that all experience has important significance in dealing with future professional knowledge learning as well as the graduating job choices. Extended practice is set for students who cannot choose the major they like in the college entrance examination or who want to work in other fields except the major self. This kind of part-time job can provide wider choices of employment for students, and the advanced practical work can let students realize the fact of working in interested fields. Then the work experience they gather can provide important reference about future choice in continuing to work in the professional or interested fields.

\subsubsection{Approaches of Course Evaluation}

Approach of course evaluation is also divided into two kinds, respectively class course examination and practice examination out of class. (Hong Xu: 2013) The class course examination is making a part-time career plan as audit standard, including motivation of kind of part-time job, required knowledge and practice time, etc. Then, the practice examination is proved by some proof and evaluation filled by the units students work for, plus a piece of part-time job practice feeling as audit standard.

In the class curriculum, teachers teach basic recruitment or interview information, and the information of department where students to go prior real working time. Meanwhile, instructors always keep in touch with students to help solve problems encountered in practice, and the difficulties they cannot solve by themselves.

\section{SUMMARY}

In summary, taking part-time job practice is somewhat reasonable and effective for students, employers and college. With the investigation, the author can basically affirms the value of part-time job practice, and put forward the ideas and expectations for setting up part-time job practice curriculum. In a sense, part-time job practice curriculum is a small bridge connecting college education with communities, and the more important thing is that the information collected from this course will be useful for the community and other education-related disciplines, so that to improve the current teaching methods, and driven other course from the social reality to meet the need of ready talent that society really wants.

\section{REFERENCES}

[1] Yi-hong Gao, Yuan Zhao, Ying Cheng, Yan Zhou, Motivation Types of Chinese College Undergraduates. Modern Foreign Languages (Quarterly) 2003(01):28-38.

[2] Xin Zhu, The Impact of College Students Part-Time Behavior on the Academic Development. China Power Education 2011(20): 174-175.

[3] Ting-ting Wen. Part Time Education: an Important Topic of Practice Education. HEILONGJIANG EDUCATION 2012(07): 74-75.

[4] Qi-bao Tang. Theory on College Students' Extracurricular Part-Time Coping Strategies. Journal of Xuzhou Education College 2008(03): 158-160.

[5] Hong $\mathrm{Xu}$. Hot Issues and Cold Reflection: Connotation, Problems and Countermeasures of Quality Education. Journal of Inner Mongolia Normal University (Educational Science) 2013(03):1-5. 